\title{
Pengembangan Lembar Kerja Peserta Didik (LKPD) Berbasis Inkuiri Terbimbing Pada Materi Laju Reaksi Di SMA Indonesia Muda
}

\author{
Laurelia Lusiana $^{1)}$, Eny Enawaty ${ }^{2)}$, Rahmat Rasmawan ${ }^{3)}$ \\ 1) Jurusan Pendidikan Kimia, FKIP Universitas Tanjungpura \\ ${ }^{2)}$ Staf Pengajar Jurusan Kimia, FKIP Universitas Tanjungpura \\ ${ }^{2)}$ Staf Pengajar Jurusan Kimia, FKIP Universitas Tanjungpura \\ laurelialusiana@student.untan.ac.id
}

\begin{abstract}
This study aims to determine the feasibility of student worksheet media based on guided inquiry on the reaction rate material and to describe the chemistry teacher's response to the developed student worksheets. This research is a research and development $(R \& D)$ using the 4-D model which is limited to the develop stage. The subject of this research is the response to 3 teachers who teach chemistry lessons in SMA. The instruments in this study were the feasibility assessment sheet and the teacher response assessment sheet. The results of data processing showed that the student worksheets media obtained material feasibility of $91.67 \%$, language feasibility of $90.62 \%$, and graphic feasibility of $93.75 \%$ with very feasible categories. the results of the calculation of the percentage of teacher response questionnaires of $89.39 \%$ with the high category. This shows that the teacher's response to the student worksheets media is very high. so that the LKPD media can be used as a complementary teaching material on the reaction rate material.
\end{abstract}

Keywords : LKPD media, Guided Inquiry, Reaction Rate, 4-D.

\section{PENDAHULUAN}

Pendidikan adalah proses yang dilakukan manusia guna mengembangkan dirinya sebaik mungkin dari dalam. Menurut Depdiknas No.20 Tahun 2003, pendidikan juga dimaknai sebagai usaha sadar, terarah mewujudkan proses pembelajaran untuk siswa secara aktif mengembangkan diri untuk memiliki kekuatan spiritual keagamaan, pengendalian diri, kepribadian, kecerdasan, akhlak mulia, serta keterampilan yang diperlukan dirinya dan masyarakat.

Mengenai ilmu kimia salah satu Ilmu Pengetahuan Alam (IPA) yang mencangkup materi tentang fenomena serta hukum alam. Berdasarkan pendapat Fadiawati (2013), ada tiga aspek yang menyatakan karakteristik ilmu kimia pertama, kimia sebagai produk terdiri dari fakta, konsep, hukum, prinsip, dan teori. Kedua, kimia sebagai proses. Ketiga, sebagai sikap. Keenan (1984:2), menyatakan bahwa ilmu kimia merupakan ilmu yang membahas tentang struktur kimia, materi, dan perubahan yang terjadi pada materi baik proses alamiah dan eksperimen yang terencana. Melalui kimia, dapat melihat proses penting dalam makhluk hidup, susunan (komposisi) suatu zat, pengunaan bahan kimia baik secara alami serta buatan, dan pelajaran ini masuk dalam kelompok pelajaran yang paling sulit bagi siswa di SMA/MA.

Pembelajaran kimia pada Kurikulum 2013 menginginkan adanya kesesuaian antara materi pembelajaran dan pengalaman dalam kehidupan sehari-hari. Agar esensi dari kurikulum 2013 dapat diaplikasikan, salah satu strategi pembelajaran untuk memperoleh pengetahuan yang pokus pada proses penemuan adalah inkuiri (Jauhar, 2011).

Roestiyah (2012), menyatakan bahwa pembelajaran berbasis inkuiri terbimbing salah satu cara yang dapat diaplikasikan oleh pendidik untuk mengajar di kelas, di mana siswa terlibat aktif sendiri memecahkan masalah tersebut, mengemukakan pendapat, merumuskan masalah, merencanakan eksperimen, melakukan percobaan, menganalisa, dan membuat kesimpulan sendiri. Menurut penelitian Wang (2011), mengungkapkan manfaat inkuiri terbimbing peserta didik memperoleh kepercayaan diri dalam kemampuan memecahkan masalah, pengem- 
bangan pemaham tentang konsep-konsep abstrak, dan kemajuan untuk belajar mandiri. Kelebihan inkuiri terbimbing meningkatkan kemandirian peserta didik, dengan memberikan pengalaman belajar secara langsung, agar siswa lebih aktif dengan penemuan menurut Sanjaya (2013).

Dengan dilaksanakannya suatu pembelajaran inkuiri terbimbing dengan menuntun peserta didik memperoleh pengetahuan melalui kegiatan pembelajaran secara mandiri, maka diperlukan perangkat pembelajaran sejenis Lembar Kerja Peserta Didik (LKPD) yang dapat mengarahkan siswa guna mencari serta berusaha mendapatkan jawaban dari permasalahan dalam pembelajaran Sukmawati (2017). Ulfah Dkk (2013) berpendapat dalam proses belajar mengajar bisa berjalan efektif, menumbulkan sikap kreatif, membuat siswa aktif, dan selama pembelajaran dapat menarik siswa serta menyenangkan apabila dilengkapi oleh adanya media bantu berupa bahan ajar, salah satu dari bahan ajar yang dapat digunakan yaitu lembar kerja peserta didik (LKPD).

Lembar kerja peserta didik (LKPD) yakni salah satu bahan pembelajaran cetak berbentuk lembar-lembaran berisikan materi atau ringkasan singkat dan petunjuk implementasi dari tugas pembelajaran kemudian tugas yang ada dalam LKPD dikerjakan oleh siswa yang berupa teori dan praktik (Prastowo, 2012). Penggunaan LKPD juga memiliki tujuan untuk mengetahui pemahaman konsep, sebagai acuan praktikum, sebagai penuntun belajar peserta didik, melatih keterampilan peserta didik dan dapat menolong peserta ddik mengimplementasikan serta memadukan konsep-konsep temuannya Pratiwi (2013).

Wawancara kepada guru mata pelajaran IPA SMA Indonesia Muda, bahwa dalam pembelajaran guru menggunakan buku paket kimia dan bahan ajar cetak berupa LKPD yang dibuat sendiri. Namun LKPD tersebut hanya dibuat tanpa isi dan prosedur yang lengkap. Proses pembelajaran di kelas dilakukan dengan metode ceramah selama kegiatan pembelajaran ada peserta didik yang memperhatikan dan yang tidak memperhatikan kadang peserta didik sibuk bermain HP. Guru juga menyebutkan bahwa peserta didik senang mengikuti pembelajaran secara berkelompok. Wawancara peserta didik setelah mengikuti pembelajaran pada materi faktor laju reaksi peserta didik senang mengikuti pembelajaran praktek karena lebih mudah memahami pembelajaran yang disampaikan peserta didik juga mengatakan senang belajar dengan menggunakan LKPD yang dibuat guru, namun LKPD yang dibuat masih kurang lengkap. Salah satu contoh tidak adanya langkah kerja dan LKPD kurang menarik. Laju reaksi merupakan satu diantara materi pembelajaran kimia yang dipelajari di SMA/MA.

Materi dari laju reaksi kali ini mempelajari tentang sub materi faktor-faktor laju reaksi yang mencakup empat faktor. Erna Tru Wulandari (2014), Faktor laju reaksi merupakan submateri yang dipelajari pada materi laju reaksi yang terdiri dari empat faktor yakni faktor konsentrasi, luas permukaan, suhu, dan katalis.

Beberapa peran pendidik pada kegiatan belajar mengajar terdiri dari: sebagai pelaksana mengajar informatif, mengatur efektivitas kegiatan belajar yang efisien, memberikan dorongan belajar untuk mengembangkan potensi peserta didik, memberikan bimbingan serta siswa berdasarkan tujuan pembelajaran, selaku penyebar pengetahuan pendidikan, sebagai penyebar untuk menciptakan suasana belajar yang tenang agar interaksi disaat belajar mengajar berlangsung efektif dan optimal, sebagai penengah dalam proses belajar, dan menilai serta mengamati perkembangan prestasi peserta didik (Sardiman, 2011).

Menurut Juwairiah (2015) pelaksanaan praktikum tidak hanya terbatas pada alat maupun bahan yang disediakan di praktikum dalam laboratorium, oleh karena itu diperlukan kreativitas guru untuk mengeksploritas apa yang tersedia di alam dan di lingkungan. Berdasarkan (Karpudewen, 2011), Education for Sustainable Development (ESD) merupakan salah satu pendekatan yang dapat digunakan untuk diterapkan agar terlaksanakannya kegiatan laboratorium yang ramah lingkungan dan aman.

Berdasarkan penelitian Sugiarti (2018), dilakukan pada 10 orang peserta didik kelas XI IPA SMA Negeri 2 Polewali diperoleh hasil uji terlaksanaan rata-rata total persentase sebesar $95 \%$ yang dikatagorikan "sangat baik", sedangkan diperoleh rata-rata total persentase dari hasil uji keterbacaan sebesar 82,50\%. Diperoleh hasil uji respon dari 3 orang guru mendapat respon positif dan dikategori "sangat baik". Berdasarkan hasil di atas dijelaskan Bahwa LKPD berbasis inkuiri terbimbing dapat menarik minat 
dan motivasi belajar siswa sehingga mampu mengoptimalkan kemampuan siswa, yang akhirnya dapat meningkatkan hasil belajar siswa. Berdasarkan uraian di atas, akan dikembangkan bahan ajar berupa lembar kerja peserta didik (LKPD) berbasis inkuiri terbimbing pada materi laju reaksi di SMA Indonesia Muda.

\section{METODE PENELITIAN}

Model penelitian serta pengembangan yang dipakai kali ini adalah model pengembangan 4D. Menurut Thiagarajan (1974) menyatakan bahwa, bagian-bagian penelitian dan pengembangan menggunakan model 4D, yaitu merupakan singkatan dari Define, Design, Devel-

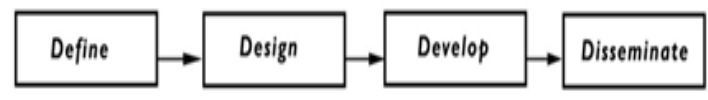

opment, and Dissemination. Hal tersebut dapat digambarkan seperti ada tertera pada gambar 1 .

Gambar 1. Pengembangan perangkat pembelajaran model 4D

Subjek penelitian adalah media lembar kerja peserta didik (LKPD) berbasis inkuiri yang akan dilakukan pengujian kelayakan oleh ahli serta terhadap 3 respon guru yang mengajar IPA kimia di SMA.

Pada tahap uji kelayakan, Pengembangan media LKPD selanjutnya dinilai oleh 3 orang ahli yaitu 3 orang ahli materi, 3 orang ahli kebahasaan, dan 3 orang ahli kegrafikan untuk menguji tingkat kelayakan terhadap media LKPD berbasis inkuiri terbimbing pada materi faktor laju reaksi.

Tahap uji respon, menggunakan respon guru terhadap LKPD berbasis inkuiri terbimbing pada materi faktor laju reaksi dengan menggunakan angket respon guru. Uji respon dilakukan terhadap 3 orang guru yang mengajar mata pelajaran Kimia.

Angket penilaian kelayakan media dan angket respon guru menggunakan skala Likert dengan skor pada lembar penilaian kelayakan yaitu skor 1 (sangat tidak layak), skor 2 (tidak layak), skor 3 ( layak), skor 4 (sangat layak). Sedangkan pada angket respon guru skala Likert digunakan untuk menghitung skor dengan empat skala penilaian (kriteria), yaitu SS (Sangat Setuju), S (Setuju), TS (Tidak Setuju), dan STS (Sangat Tidak Setuju).

Volume 5| Nomor 1|Mei 2021|Page 51-58

\section{HASIL DAN PEMBAHASAN}

Bersumber dari hasil wawancara via chat online pada tanggal 25 Juli 2020 dan wawancara langsung ke sekolah pada tanggal 27 Juli 2020 terhadap guru yang mengajar mata pelajaran kimia di SMA Indonesia Muda. Pada saat proses pembelajaran kimia berlangsung sebagian dari peserta didik yang memperhatikan dan sebagiannya lagi dari peserta didik yang tidak memperhtikan kadang peserta didik sibuk bermain HP.

Di penelitian ini guru menghadapi kendala pada saat menyampaikan pembelajaran dalam kelas. Proses penyampaian materi dilakukan dengan metode ceramah dengan bantuan buku paket. Guru pernah menggunakan LKPD yang dibuat sendiri namun LKPD yang digunakan hanya dibuat begitu saja/LKPD yang digunakan kurang lengkap secara isi dan prosedur. Akibat dari media LKPD yang kurang lengkap membuat peserta didik pada saat praktikum selalu menanyakan alat bahan dan prosedur kerja sehingga menganggu jam pelajaran yang menyebabkan KD pembelajaran yang digunakan tidak tercapai.

Berdasarkan kenyataan yang diperoleh di lapangan, bahwa permasalahan yang dihadapi oleh guru adalah media yang digunakan belum lengkap sehingga peserta didik belum bisa berperan aktif dalam proses pembelajaran. Dari permasalahan yang ada, harapannya peserta didik dapat mengikuti pembelajaran secara terampil dan aktif dengan berbantuan media pembelajaran yang dikembangkan. Ditambah lagi dengan media pembelajaran yang mampu memudahkan siswa memahami bahasan materi yang disampaikan.

Oleh sebab itu, diperlukan media pembelajaran yang dapat memudahkan guru menyajikan pembelajaran dan membuat peserta didik terampil dan aktif saat proses pembelajaran berlangsung. Untuk itu dikembangkan media pembelajaran berupa LKPD yang dilengkapi isi dan prosedur kerja yang lengkap dengan model pembelajaran inkuiri terbimbing yang memiliki sintak yang dapat menuntun peserta didik untuk lebih terampil dan aktif dalam proses pembelajaran. Media LKPD yang dibuat memuat percobaan-percobaan dengan gambar menarik sesuai dengan tema percobaan yang terdapat dalam materi faktor-faktor yang mempengaruhi laju reaksi. Di dalam media LKPD juga telah disediakan alat dan bahan serta prosedur kerja yang 
lengkap untuk memudahkan siswa dalam melakukan percobaan.

Analisis peserta didik dalam penelitian ini bertujuan mengali informsi terkait karakteristik peserta didik dan mencari informasi kisaran usia peserta didik. Bersumber dari wawancara dengan guru IPA kelas XI di SMA Indonesia Muda bahwa tahapan perkembangan siswa kelas XI Sains di SMA Indonesia Muda tahun ajaran 2020/2021 berada pada tahap perkembangan usia remaja awal (15-17 tahun) ciri pokok perkembangan ditahap ini adalah perkembangan anak sudah mulai berpikir abstrak dan logis. Sedangkan ditinjau dari perkembangan kognisis sosial, anak pada usia 12 tahun ke atas kemampuan berpikir kritis yang berkembang sejalan dengan usia dan pengalaman. Dengan usia remaja awal 12 tahun ke atas peserta didik dapat berfikir kritis dalam memecahkan masalah yang terdapat dalam media LKPD dan lebih terampil melakukan percobaan yang terdapat dalam media LKPD.

Analisis Kurikulum dilakukan dengan mengkaji KD dan Indikator kimia kelas XI sains SMA Indonesia muda. Hasil analisis indikator yang harus dicapai dan submateri yang dipelajari ditunjukan pada tabel 1

Tabel 1. Analisis KD dan Indikator

\section{Kompetensi Dasar}

4.7. Merancang, melakukan, dan menyimpulkan serta menyajikan hasil percobaan faktorfaktor yang mempengaruhi laju reaksi dan orde reaksi.

\begin{tabular}{l} 
Indikator \\
\hline 4.7.1 Melakukan percobaan sederhana tentang \\
faktor-faktor yang mempengaruhi laju reaksi. \\
4.7.2 Mempresentasikan data percobaan ten- \\
tang faktor-faktor yang mempengaruhi laju \\
reaksi.
\end{tabular}

Analisis konsep bertujuan guna mengidentifikasi konsep pokok materi yang diajarkan. Berdasarkan analisis tugas, maka dapat dibuat suatu hubungan keterkaitan konsep-konsep yang ada serta relevan sehingga membentuk peta konsep.

Pemilihan media dilakukan menyesuaikan dengan analisis konsep dan analiss tugas pada tahapan sebelumnya, pemilihan media harus relevan dengan karakteristik materi. Oleh karena itu, media yang dipilih adalah LKPD Berbasis Inkuiri Terbimbing pada Materi Laju Reaksi yang dapat menunjang tercapainya KD pembelajaran dan peserta didik tidak perlu lagi menanyakan alat bahan serta prosedur kerja. Dengan adanya sintak inkuiri terbimbing menjadikan siswa lebih terampil menjalankan praktikum.

Rancangan awal media pembelajaran atau sumber pembelajaran yang dipilih dalam penelitian ini yaitu LKPD berbasis inkuiri terbimbing pada materi laju reaksi kelas XI semester 1 , selanjutnya dilakukan rancangan produk awal. Pengembangan rancangan produk awal yakni draf kasar dari produk LKPD berbasis inkuiri terbimbing pada materi laju reaksi yang akan dibuat berupa storyboard.

Hasil uji kelayakan materi media LKPD berbasis inkuiri terbimbing pada materi laju reaksi dapat

Dilihat pada tabel 2.

Tabel 2. Hasil uji kelayakan materi media LKPD

\begin{tabular}{|c|c|c|c|}
\hline \multirow[t]{2}{*}{ No } & \multirow[b]{2}{*}{ Butir Pernyataan } & \multicolumn{2}{|c|}{ Skor Ahir } \\
\hline & & $\mathrm{P} \%$ & $\begin{array}{c}\text { Krite- } \\
\text { ria }\end{array}$ \\
\hline 1 & $\begin{array}{lr}\text { Materi laju reaksi } \\
\text { pada LKPD yang } \\
\text { disajikan relevan } \\
\text { dengan kompetensi } \\
\text { dasar (KD) }\end{array}$ & 91,67 & $\begin{array}{l}\text { Sangat } \\
\text { Layak }\end{array}$ \\
\hline 2 & $\begin{array}{lr}\text { Konsep } & \text { yang } \\
\text { disajikan } & \text { sesuai } \\
\text { dengan konsep } & \text { para } \\
\text { ahli } & \end{array}$ & 83,33 & $\begin{array}{l}\text { Sangat } \\
\text { Layak }\end{array}$ \\
\hline 3 & $\begin{array}{lr}\text { Informasi } & \text { tentang } \\
\text { materi laju reaksi } \\
\text { memotivasi peserta } \\
\text { didik untuk belajar }\end{array}$ & 100 & $\begin{array}{l}\text { Sangat } \\
\text { Layak }\end{array}$ \\
\hline Rat: & rata & & $\begin{array}{l}\text { Sanga } \\
\text { Layak }\end{array}$ \\
\hline
\end{tabular}

Berdasarkan tabel 2 diketahui bahwa nilai kelayakan materi secara keseluruhan sebesar 91,67\% yang dikategorikan sangat layak. Sehingga dapat disimpulkan materi dalam media LKPD yang dikembangkan sesuai dengan indikator penilaian.

\section{Revisi Materi}

Pada bagian materi dilakukan perbaikan pada bagian teori laju reaksi dan faktor laju reaksi karena teori yang digunakan kurang tepat sehingga informasi yang disampaikan kurang lengkap. Dilakukan perbaikan ditampilkan pada gambar 2 . 


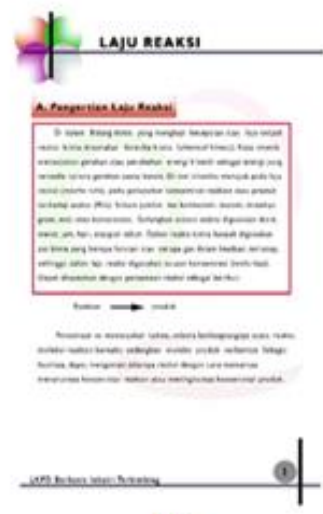

(1)

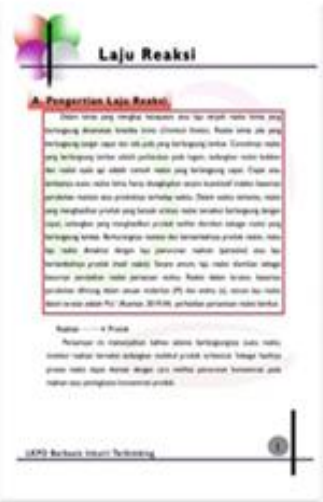

(2)
Gambar 2. (1) materi laju reaksi sebelum revisi dan (2) materi laju reaksi setelah revisi.

Hasil uji kelayakan kegrafikan media LKPD berbasis inkuiri terbimbing pada materi laju reaksi dapat

Dilihat pada tabel 3.

Tabel 3. Hasil uji kelayakan kegrafikan media LKPD

\begin{tabular}{|c|c|c|c|}
\hline \multirow[t]{2}{*}{ No } & \multirow[b]{2}{*}{ Butir Pernyataan } & \multicolumn{2}{|c|}{ Skor Ahir } \\
\hline & & $\mathrm{P} \%$ & $\begin{array}{c}\text { Krite- } \\
\text { ria }\end{array}$ \\
\hline 1 & $\begin{array}{l}\text { Jenis dan ukuran hu- } \\
\text { ruf di dalam LKPD } \\
\text { dapat terbaca jelas. }\end{array}$ & 100 & $\begin{array}{l}\text { Sangat } \\
\text { Layak }\end{array}$ \\
\hline 2 & $\begin{array}{l}\text { Tata letak kalimat } \\
\text { memudahkan pem- } \\
\text { baca. }\end{array}$ & 100 & $\begin{array}{l}\text { Sangat } \\
\text { Layak }\end{array}$ \\
\hline 3 & $\begin{array}{l}\text { Pemilihan ilustrasi/ } \\
\text { gambar/ foto dapat } \\
\text { memperjelas infor- } \\
\text { masi yang disam- } \\
\text { paikan sesuai dengan } \\
\text { materi. }\end{array}$ & $\begin{array}{l}91,6 \\
7\end{array}$ & $\begin{array}{l}\text { Sangat } \\
\text { Layak }\end{array}$ \\
\hline 4 & $\begin{array}{l}\text { Tampilan teks, ilus- } \\
\text { trasi,elemen dekoratif } \\
\text { lainnya sesuai desain } \\
\text { yang ditampilkan. }\end{array}$ & $\begin{array}{l}83,3 \\
3\end{array}$ & $\begin{array}{l}\text { Sangat } \\
\text { Layak }\end{array}$ \\
\hline & &, $75 \%$ & $\begin{array}{l}\text { Sangat } \\
\text { Layak }\end{array}$ \\
\hline
\end{tabular}

Berdasarkan tabel 3 diketahui bahwa nilai kelayakan kegrafikan secara keseluruhan sebesar 93,75\% yang dikategorikan sangat layak. Sehingga dapat diketahui bahwa materi yang termuat dalam media LKPD yang dikembangkan sesuai dengan indikator penilaian.
Pada bagian sampul depan media LKPD mengalami perbaikan untuk menyesuaikan warna latar dengan tulisan yang digunakan. Dilakukan perbaikan dan dapat dilihat pada gambar 3 .

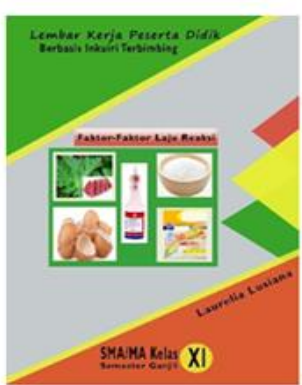

(1)

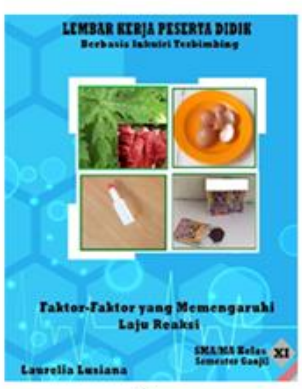

(2)
Gambar 3. (1) sampul depan sebelum revisi (2) sampul depan setelah revisi

Selanjutnya dilakukan perbaikan pada letak gambar dalam isi media LKPD untuk dibuat lebih menarik dengan desain sendiri. Dilakukan perbaikan dan dapat dilihat pada gambar 4.

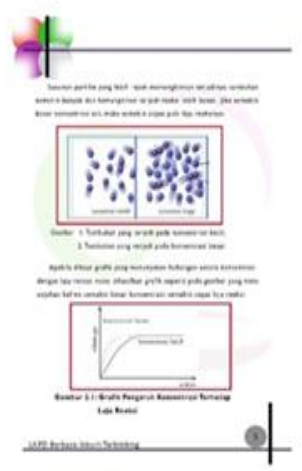

(1)

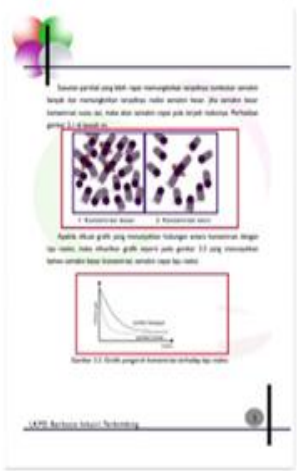

(2)
Gambar 4. (1) letak gambar sebelum revisi dan (2) letak gambar setelah revisi.

Hasil uji kelayakan bahasa media LKPD berbasis inkuiri terbimbing pada materi laju reaksi dapat

Dilihat pada tabel 4.

Tabel 4. Hasil uji kelayakan bahasa media LKPD 


\begin{tabular}{|c|c|c|c|}
\hline $\mathrm{N}$ & Butir Pernyataan & $\mathrm{P} \%$ & Kriteria \\
\hline 1 & $\begin{array}{l}\text { Kalimat yang } \\
\text { digunakan efektif. }\end{array}$ & 91,66 & $\begin{array}{l}\text { Sangat } \\
\text { Layak }\end{array}$ \\
\hline 2 & $\begin{array}{l}\text { Bahasa yang } \\
\text { digunakan jelas. }\end{array}$ & 91,66 & $\begin{array}{l}\text { Sangat } \\
\text { Layak }\end{array}$ \\
\hline 3 & $\begin{array}{l}\text { Bahasa dalam } \\
\text { LKPD mudah } \\
\text { dipahami siswa }\end{array}$ & 100 & $\begin{array}{l}\text { Sangat } \\
\text { Layak }\end{array}$ \\
\hline 4 & $\begin{array}{l}\text { Mendorong siswa } \\
\text { untuk berdiskusi } \\
\text { dengan baik. }\end{array}$ & 91,66 & $\begin{array}{l}\text { Sangat } \\
\text { Layak }\end{array}$ \\
\hline 5 & $\begin{array}{l}\text { Bahasa dalam } \\
\text { LKPD sesuai } \\
\text { tingkat perkem- } \\
\text { bangan emosional } \\
\text { peserta didik. }\end{array}$ & 91,66 & $\begin{array}{l}\text { Sangat } \\
\text { Layak }\end{array}$ \\
\hline 6 & $\begin{array}{l}\text { Bahasa dalam } \\
\text { LKPD sejalan } \\
\text { dengan tingkat } \\
\text { perkembangan in- } \\
\text { telektual siswa }\end{array}$ & 91,66 & $\begin{array}{l}\text { Sangat } \\
\text { Layak }\end{array}$ \\
\hline 7 & $\begin{array}{l}\text { Tata bahasa da- } \\
\text { lam LKPD } \\
\text { sesuai kaidah } \\
\text { bahasa Indone- } \\
\text { sia yang baik } \\
\text { dan benar. }\end{array}$ & 83,33 & $\begin{array}{l}\text { Sangat } \\
\text { Layak }\end{array}$ \\
\hline 8 & $\begin{array}{l}\text { Bahasa dalam } \\
\text { LKPD sesuai } \\
\text { dengan Ejaan Ba- } \\
\text { hasa Indonesia } \\
\text { (EYD). }\end{array}$ & 83,33 & $\begin{array}{l}\text { Sangat } \\
\text { Layak }\end{array}$ \\
\hline
\end{tabular}

Berdasarkan tabel 4 diketahui bahwa nilai kelayakan bahasa secara keseluruhan sebesar $90,62 \%$ yang dikategorikan sangat layak. Sehingga dapat diketahui bahwa materi yang digunakan dalam media LKPD yang dikembangkan sesuai dengan indikator penilaian.

3. Revisi Bahasa

Pada bagian ini dilakukan perbaikan pada tanda baca yang digunakan dalam media LKPD dengan menggunakan tanda baca yang tepat. Dilakukan perbaikan dan dapat dilihat pada gambar 5 .

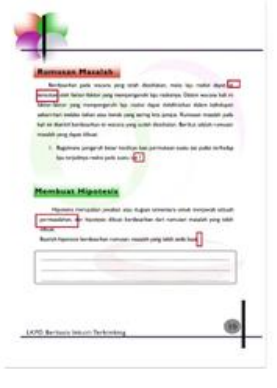

(1)

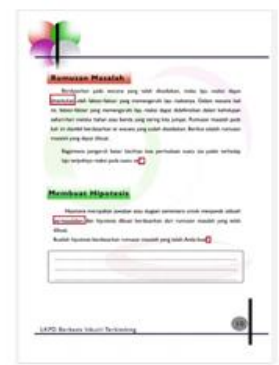

(2)
Gambar 5. (1) tanda baca sebelum revisi dan (2) tanda baca setelah revisi

Uji angket reson guru bertujuan untuk mengetahui penilaian guru kimia mengenai LKPD yang dibuat. Hal ini dilakukan karena LKPD akan digunakan oleh guru dalam proses pembelajaran sebagai perlengkapan bahan ajar utama. Oleh sebab itu, penilaian dari guru pelajaran Kimia perlu dilakukan agar LKPD dapat membantu mengatasi permasalahan pada materi laju reaksi khususnya faktor-faktor yang memengaruhi laju reaksi.

Hasil uji respon guru terhadap media LKPD dapat dilihat pada tabel 5.

Tabel 5. Hasil uji respon guru

\begin{tabular}{|c|c|c|c|}
\hline \multirow[t]{2}{*}{ No } & \multirow[t]{2}{*}{ Butir Pernyataan } & \multicolumn{2}{|c|}{ Hasil Respon } \\
\hline & & Skor & kriteria \\
\hline 1 & $\begin{array}{lr}\text { Tampilan } & \text { kese- } \\
\text { luruhan lembar kerja } \\
\text { peserta } & \text { didik } \\
\text { menarik. } & \end{array}$ & 91,66 & $\begin{array}{l}\text { Sangat } \\
\text { Tinggi }\end{array}$ \\
\hline 2 & $\begin{array}{l}\text { LKPD Tidak sesuai } \\
\text { dengan KD. }\end{array}$ & 91,66 & $\begin{array}{l}\text { Sangat } \\
\text { Tinggi }\end{array}$ \\
\hline 3 & $\begin{array}{l}\text { LKPD memiliki } \\
\text { judul yang jelas. }\end{array}$ & 83,33 & $\begin{array}{l}\text { Sangat } \\
\text { Tinggi }\end{array}$ \\
\hline 4 & $\begin{array}{l}\text { LKPD memiliki } \\
\text { tujuan praktikum } \\
\text { yang jelas }\end{array}$ & 100 & $\begin{array}{l}\text { Sangat } \\
\text { Tinggi }\end{array}$ \\
\hline 5 & $\begin{array}{l}\text { Komponen-kompo- } \\
\text { nen keseluruhan da- } \\
\text { lam LKPD tidak } \\
\text { lengkap. }\end{array}$ & 83,33 & $\begin{array}{l}\text { Sangat } \\
\text { Tinggi }\end{array}$ \\
\hline 6 & $\begin{array}{l}\text { LKPD } \\
\text { digunakan dapat } \\
\text { membantu saya da- } \\
\text { lam mengajarkan } \\
\text { materi faktor laju } \\
\text { reaksi. }\end{array}$ & 100 & $\begin{array}{l}\text { Sangat } \\
\text { Tinggi }\end{array}$ \\
\hline 7 & $\begin{array}{l}\text { LKPD } \\
\text { digunakan }\end{array}$ & 91,66 & $\begin{array}{l}\text { Sangat } \\
\text { Tinggi }\end{array}$ \\
\hline
\end{tabular}




\begin{tabular}{|c|c|c|c|}
\hline & $\begin{array}{l}\text { dapat membantu } \\
\text { saya dalam mengem- } \\
\text { bangkan sikap kre- } \\
\text { atif peserta didik. }\end{array}$ & & \\
\hline 8 & $\begin{array}{l}\text { Topik permasalahan } \\
\text { yang terdapat dalam } \\
\text { LKPD mudah dipa- } \\
\text { hami peserta didik. }\end{array}$ & 91,66 & $\begin{array}{l}\text { Sangat } \\
\text { Tinggi }\end{array}$ \\
\hline 9 & $\begin{array}{l}\text { Bahasa di dalam } \\
\text { LKPD tidak sesuai } \\
\text { dengan usia peserta } \\
\text { didik. }\end{array}$ & 83,33 & $\begin{array}{l}\text { Sangat } \\
\text { Tinggi }\end{array}$ \\
\hline 10 & $\begin{array}{l}\text { Lembar kerja peserta } \\
\text { didik menggunakan } \\
\text { kalimat yang komu- } \\
\text { nikatif. }\end{array}$ & 83,33 & $\begin{array}{l}\text { Sangat } \\
\text { Tinggi }\end{array}$ \\
\hline 11 & $\begin{array}{l}\text { Petunjuk umum dan } \\
\text { khusus yang terdapat } \\
\text { dalam lembar kerja } \\
\text { peserta didik sulit } \\
\text { dipahami. }\end{array}$ & 83,33 & $\begin{array}{l}\text { Sangat } \\
\text { Tinggi }\end{array}$ \\
\hline \multicolumn{2}{|c|}{ Rata-rata } & & Sangat \\
\hline \multicolumn{2}{|c|}{89,39} & & Tinggi \\
\hline
\end{tabular}

Berdasarkan tabel 5 diketahui bahwa presentase rata-rata hasil respon guru dari 11 butir pernyataan sebesar $89,38 \%$ yang dikategorikan sangat tinggi. Berdasarkan hasil respon menunjukan bahwa media LKPD yang dikembangkan dapat digunakan sebagai media yang dapat membantu guru dalam menyampaikan materi laju reaksi terutama pada submateri faktor laju reaksi.

Berdasarkan tabel di atas, dapat dilihat nilai pengskoran berdasarkan tiap butir pernyataan memiliki nilai dengan kategori sangat tinggi. Dapat disimpulkan bahwa berdasarkan tampilan, judul, kompetensi dasar, tujuan praktikum, komponen-komponen keseluruan LKPD, topik permasalahan dalam LKPD, bahasa yang digunakan, serta petunjuk umum yang terdapat dalam LKPD sudah sesuai dengan perkembangan peserta didik dan semua yang wajib dicantumkan dalam LKPD sudah sesuai dengan media pembelajaran yang seharusnya digunakan sebagai penuntun belajar BNSP (2012). LKPD yang dikembangkan dapat membantu siswa meningkatkan aktivitas keterampilan proses, konsep, pengembangan berfikir logis tentang gagasan-gagasan tertentu Hidayati (2013).

\section{KESIMPULAN}

Media LKPD berbasis inkuiri terbimbing pada materi laju reaksi sangat layak digunakan sebagai media pembelajaran. Penilayakan kelayakan ahli menunjukan bahwa media LKPD memperoleh kelayakan materi sebesar 91,67\%, kelayakan bahasa sebesar 90,62\%, dan kelayakan kegrafikan sebesar 93,75\%. Respon guru terhadap media lembar kerja peserta didik (LKPD) berbasis inkuiri terbimbing sebesar $89,39 \%$ yang dikategorikan sangat tinggi.

\section{DAFTAR PUSTAKA}

Andi Prastowo. 2012. Panduan Kreatif Membuat Bahan Ajar Inovatif. Yogyakarta: Diva Press.

BSNP. 2012. Diskripsi Item Kegrafikan SMPSMA-SMK. Jakarta: BSNP.

Dian, Pratiwi. 2013. Pengemangan Lembar Kerja Siswa (LKS) Berbasis Pendekatan Saintifik Pada Materi Hukum Hukum Dasr Kimia Di SMA Negeri 10 Menengah Atas.Jurnal Edu-Sains Volume 4 (2): 30-36.

Fadiawati, N. 2013. Perkembangan Konsepsi Pembelajaran Tentang Struktur Atom Dari SMA Hingga Perguruan Tinggi. Perpustakaan Pendidikan Universitas Indonesia.

Hidayat, Sholeh.2013. Pengembangan Kurikulum Baru. Bandung: PT.Remaja Rosdakarya Bandung.

Jauhar, Muhammad. 2011. Implementasi PAIKEM dari Behavioristik sampai Kontruktivistik. Jakarta: Prestasi Pustaka Publisher.

Juwairiah. 2015. Implementasi Pembelajaran IPA-Kimia dengan menggunakan Percobaan Sederhana Berbasis Bahan Alam untuk Meningkatkan Hasil Belajar Kelas VII SMPN 2 Muara Batu. Jurnal Bio-Natural (Jurnal Pendidikan Biologi), 1(2), 2-3.

Karpudewen, M., Ismail, Z., \& Mohamed, N. 2011. Green Chemistry: Education 
Prospective Science Teacher in Education For Sustainable Development At School of Education Studies, USM. Journal of Social Sciences, 7(1), 42-50.

Keenan, Kleinfelter dan Wood. 1984. Kimia untuk Universitas Edisi Keenam Jilid 2. Jakarta: Erlangga.

Roestiyah, N.K.2012. Strategi Belajar Mengajar. Jakarta: Rinaka Cipta.

Sanjaya, Wina. 2013. Penelitian Pendidikan, Jenis, Metode dan Prosedur. Jakarta: Kencana Prenada Media Group.

Sardiman. 2011. Interaksi dan Motivasi Belajar Mengajar. Jakarta: Rajawali Pers.

Sugiarti. 2018. Pengembangan Lembar Kerja Siswa (LKS) Berbasis Inkuiri Terbimbing pada Materi Pokok Laju Reaksi Untuk Siswa Kelas XI IPA SMA. Jurnal Nalar Pendidikan.Vol:6. No:1.

Thiagarajan, Sivasailam, Semmel, Dorothy S. \& Semmel, Melvyn I. 1974. Instructional Development for Training Teachers of Exceptional Children. Bloomington: Indiana University.

Ulfa Septi, M. Rahmad, And Azhar. 2018. Efektivitas Penggunaan LKPD Bermuatan Kecerdasan Kompheresif Berbasis Model PBL Pada Pembelajaran Fisika. Jurnal Online Mahasiswa. Universitas Riau.

Wulandari, Erna Tri dan Anis Dyah Rufaida. 2014. Kimia Peminatan Matematika dan Ilmu-Ilmu Alam. Klaten: Intan Pariwara. 